\title{
DINAMIKA PERUBAHAN SOSIAL DAN HUKUM ISLAM
}

\author{
Muh Turizal Husein \\ abiturizal68@gmail.com \\ (Dosen Fakultas Agama Islam Universitas Muhammadiyah Tangerang)
}

\begin{abstract}
Abtrak:
Dinamika perubahan sosial dan hukum Islam saling memiliki keterkaitan dalam melakukan perubahan. Satu sisi perubahan sosial karena hukum Islam. Di sisi lain, perubahan hukum Islam karena perubahan sosial. Keberadaan hukum Islam yang dibawa oleh Rasulullah SAW. dengan jelas merubah sosial masyarakat pada waktu itu dari masyarakat jahiliyyah yang berpegang kepada adat kebiasaan mereka menjadi masyarakat Islam yang berpegang kepada hukum Islam. Tetapi hukum Islam juga melakukan perubahan karena terjadinya perubahan sosial. Sesuai dengan kaidah fikih yang dibuat oleh fuqaha: "berubahnya fatwa dengan sebab berubahnya masa, tempat, keadaan (niat) dan adat kebiasaan”. Dengan melakukan perubahan hukum, maka hukum Islam itu dinamis, dan mampu beradaptasi, sehingga hukum Islam itu op tu date sesuai dengan perkembangan zaman dan perubahan sosial.
\end{abstract}

\section{Kata Kunci: Perubahan, Sosial, Hukum Islam}

\section{A. Pendahuluan}

Gairah peradaban manusia dalam sejarahnya selalu tumbuh dan berkembang secara aktif seiring munculnya perubahanperubahan yang terjadi dalam sejarah kehidupan manusia itu sendiri. Sebagai makhluk yang paripurna, manusia senantiasa berusaha dan berjuang memenuhi kebutuhan hidup dan kebersamaannya di tengah manusia lainnya. Perjuangan memenuhi kebutuhan hidup ini telah memotivasi manusia untuk menggunakan akal budinya secara maksimal di manapun manusia itu berada. Karena tuntutan pemenuhan kebutuhan naluri kehidupannya. Beberapa rumusan atau definisi lain manusia disebutkan sebagai Homo Sapiens, artinya makhluk yang mempunyai budi, maka manusia sebagai makluk yang berakal budi (rational animal) selalu berpikir untuk bagaimana ia menghadapi tuntutantuntutan naluriah itu.

Perubahan pada masyarakat merupakan gejala yang lazim, yang berdampak perubahan dalam setiap sendisendi kehidupan manusia. Penemuan- penemuan baru di bidang teknologi, terjadinya revolusi, modernisasi dan seterusnya yang terjadi di suatu tempat, dengan cepat dapat yang diketahui oleh masyarakat tentunya sangat memotivasi minat masyarakat dalam melakukan perubahan-perubahan pada diri mereka. Dinamika perubahan sosial dan Islam (hukum Islam) saling memiliki keterkaitan dalam melakukan perubahan. Satu sisi perubahan sosial karena hukum Islam. Di sisi lain, perubahan hukum Islam (mu'amalah) karena perubahan sosial. Keberadaan hukum Islam yang dibawa oleh Rasulullah Saw dengan jelas merubah sosial kultur masyarakat pada waktu itu dari masyarakat jahiliyyah yang berpegang kepada adat kebiasaan mereka menjadi masyarakat Islam yang berpegang kepada hukum Islam. Tetapi hukum Islam juga melakukan perubahan karena terjadinya perubahan sosial. Sesuai dengan kaidah fikih yang dibuat oleh fuqaha, "berubahnya fatwa dengan sebab berubahnya masa, tempat, keadaan (niat) dan adat kebiasaan". Dengan melakukan perubahan hukum, maka hukum Islam itu 
dinamis, dan mampu beradaptasi, sehingga hukum Islam itu op tu date sesuai dengan perkembangan zaman dan perubahan sosial.

Hukum Islam yang bersumber kepada al-Qur'an dan Sunnah merupakan peraturan dan tatanan yang datang dari Allah yang bertujuan untuk mengatur berbagai aspek kehidupan manusia, namun keduanya memiliki daya jangkau yang terbatas. Sedangkan perubahan sosial dan permasalahan sosial akan selalu tumbuh dan berkembang dan menuntut kepastian hukum. Permasalahan hukum diberbagai aspeknya di masa lampau tidak pernah terhayalkan timbul, namun di masa kontemporer timbul dan berkembang dengan cepat. Padahal al-Qur'an turunnya telah berakhir. Sedangkan sunnah tidak ada lagi yang muncul karena Rasulullah Saw. telah wafat. Sementara tidak semua permasalahan kehidupan manusia sebagai individu atau sosial masyarakat yang perlu ditetapkan hukumnya terekam oleh alQur'an dan sunnah Rasulullah SAW.

Perkembangan dunia yang semakin maju disertai dengan era globalisasi dan perkembangan ilmu pengetahuan dan teknologi yang pesat dalam beberapa bidang kehidupan masyarakat, seperti medis, hukum, sosial serta ekonomi telah membawa pengaruh yang besar, termasuk persoalan-persoalan hokum. ${ }^{1}$ Masyarakat Islam sebagai suatu bagian yang tidak terpisahkan dari dunia, tidak dapat melepaskan diri dari persoalan-persoalan yang menyangkut kedudukan hukum suatu persoalan. Persoalan-persoalan baru yang status hukumnya sudah jelas dan tegas yang dinyatakan secara eksplisit dalam alQur'an dan al-Hadis, tidak akan menimbulkan pro dan kontra di kalangan umat Islam. Akan tetapi, terhadap

\footnotetext{
${ }^{1}$ Musthafa Muhammad az-Zarqa, Hukum Islam dan Perubahan Sosial (Studi Komparatif Delapan Mazhab ) Terj. Ade Dedi Rohayana (Jakarta: Rineka Cipta, 2000), hlm. 45.
}

persoalan-persoalan baru yang belum jelas status hukumnya dalam kedua sumber itu, menuntut para Ulama untuk memberi solusi dan jawaban yang cepat dan tepat agar hukum Islam menjadi responsif dan dinamis.

Penulis dalam makalah ini membatasi penulisan terkait perubahan sosial dengan penerapan hukum Islam. Kajian ini dalam rangka memperkuat pernyataan yang didukung oleh argumen tentang dinamisasi dan kemampuan beradaptasi hukum Islam terhadap perubahan sosial, dengan judul "Dinamika Perubahan Sosial dan Hukum Islam ".

\section{B. Pengertian Perubahan Sosial dan Hukum Islam \\ 1. Perubahan Sosial}

Persoalan-persoalan mengenai pembatasan atas pengertian perubahan sosial telah banyak dibahas oleh para sosiolog. Untuk menghindari kekaburan dalam pemahaman, maka pembicaraan mengenai perubahan sosial bisa dikembalikan kepada beberapa pendapat yang sebelumnya sudah dikemukakan para sosiolog terkemuka. Dari terminologi yang dimunculkan tersebut, akan dapat dikemukakan apa sesungguhnya perubahan sosial, dan dalam konteks apa perubahan sosial itu dibicarakan.

Rogers et.al. mengemukakan bahwa perubahan sosial adalah suatu proses yang melahirkan perubahan-perubahan didalam struktur dan fungsi dari suatu sistem kemasyarakatan. $^{2} \quad$ Sedangkan Selo Soemarjan dan Soelaeman Soemardi mengemukakan bahwa perubahan sosial diartikan sebagai suatu variasi dari caracara hidup yang telah diterima, baik karena perubahan-peubahan kondisi geografis, kebudayaan material, komposisi penduduk, idiologi, maupun karena adanya difusi atau

${ }^{2}$ Sugihen, Bahrein T., Sosiologi Pedesaan (Suatu Pengantar),(Raja Grafindo Persada, Jakarta, 1997) hlm. 55. 
penemuan-penemuan baru dalam masyarakat tersebut. $^{3}$

Setiap perubahan-perubahan sosial yang terjadi pada seseorang atau salah satu lembaga kemasyarakatan, tentu akan membawa dampak ke lembaga-lembaga kemasyarakatan lainnya. Pada umumnya suatu perubahan di bidang tertentu akan mempengaruhi bidang-bidang lainnya. Masalah kemudian sampai seberapa jauh suatu lembaga kemasyarakatan dapat mempengaruhi lembaga-lembaga kemasyarakatan lainnya, atau sampai sejauh manakah seseorang dapat bertahan terhadap rangkaian perubahan-perubahan yang dialami lembaga kemasyarakatan lainnya?. Soerjono Soekanto merumuskan bahwa perubahan sosial adalah segala perubahan-perubahan pada lembagalembaga kemasyarakatan di dalam suatu masyarakat, yang mempengaruhi sistem sosialnya, termasuk didalamnya nilai-nilai, sikap-sikap, dan pola prilaku diantara kelompok-kelompok dalam masyarakat. ${ }^{4}$

Soerjono Soekanto mengutip pendapatnya Gillin dan Gillin serta Samuel Koenig. Di mana menurut Gillin dan Gillin bahwa perubahan-perubahan sosial adalah suatu variasi dari cara hidup yang telah diterima. Perubahan-perubahan itu terjadi baik karena perubahan-perubahan kondisi geografis, kebudayaan material, komposisi penduduk, ideologi maupun karena adanya difusi ataupun penemuan-penemuan baru dalam masyarakat. Sedangkan menurut Samuel Koenig, perubahan sosial menunjuk pada modifikasi-modifikasi yang terjadi dalam pola-pola kehidupan manusia. Modifikasi-modifikasi itu terjadi karena berbagai sebab, baik sebab-sebab intern maupun sebab-sebab ekstern ${ }^{5}$.Dalam hal ini para sosiolog pada umumnya

${ }^{3}$ Soekanto, Soerjono, Sosiologi Suatu Pengantar, (Raja Grafindo Persada, Jakarta, 1994) hlm. 384.

${ }^{4}$ Soekanto, Soerjono, Pokok-Pokok Sosiologi Hukum, (Raja Grafindo Persada, Jakarta, 2001) hlm 89

${ }^{5}$ Ibid, Soekanto, Soerjono, hlm. 337 meyakini bahwa perubahan sosial adalah gejala sosial yang sangat wajar dan merupakan ciri utama masyarakat, di mana masyarakat yang dinamis adalah masyarakat yang terus bergerak dalam rangka menemukan sesuatu yang baru. Sebagai gejala yang wajar, maka hampir tidak ada masyarakat yang tidak berubah. Masyarakat yang mengalami intensitas perubahan sosial merupakan masyarakat yang memiliki dinamika interaksi sosial yang cukup tinggi, dan demikian pula sebaliknya. ${ }^{6}$

\section{Hukum Islam}

Syariat Islam secara etimologi berarti "jalan-jalan yang bisa di tempuh air", maksudnya adalah jalan yang di lalui manusia untuk menuju allah. Syariat Islamiyyah adalah hukum atau peraturan Islam yang mengatur seluruh sendi kehidupan umat Islam. Selain berisi hukum, aturan dan panduan peri kehidupan, syariat Islam juga berisi kunci penyelesaian seluruh masalah kehidupan manusia baik di dunia maupun di akhirat.

Dalam menempatkan suatu hukum pada posisi yang fungsional dalam menghadapi fenomena perubahan sosial, diperlukan suatu metodologi disertai kemampuan membaca perkembangan zaman. Banyak perangkat ilmu bantu yang bisa menopang perumusan hukum menjadi aplikatif, seperti ilmu-ilmu tafsir, tarikh, dan ilmu tata bahasa Arab. Diharapkan melalui pendekatan konvergensi antara ilmu ushul fiqh dan ilmu-ilmu lainnya akan dapat mengurangi formalisme hukum Islam. Dalam konteks ini, pemaknaan hukum Islam tidak harus dilihat dari perspektif nilai saja, tetapi perlu dicari keterkaitan secara organik dan struktural dalam kehidupan sosial. Di sinilah letak pentingnya fenomena transformasi pemikiran hukum Islam, tidak hanya dilihat sebagai fenomena keagamaan saja. Transformasi pemikiran hukum Islam di

${ }^{6}$ Ary H. Gunawan, Sosiologi Pendidikan, pp. hlm. 4-13. 
Indonesia merupakan suatu pergumulan kreatif antara Islam dengan masyarakat Indonesia, antara nilai-nilai Islam dengan kenyataan struktural masyarakat. Oleh karena itu, maka program pembaruan pemikiran hukum Islam adalah suatu bagian yang tidak terpisahkan dari proses kehidupan masyarakat yang selalu berubah.

Berbagai upaya pembaruan pemikiran hukum Islam (fiqh) diperlukan beberapa syarat; pertama, adanya tingkat pendidikan yang tinggi dan keterbukaan dari masyarakat muslim; kedua, hukum Islam (figh) harus dipandang sebagai variasi suatu keragaman yang bersifat partikular yang selalu dibatasi oleh dimensi ruang dan waktu; ketiga, memahami faktor sosio-kultural dan setting politik yang melatarbelakangi lahirnya suatu produk hukum agar dapat memahami partikularisme dari pemikiran hukum tersebut; keempat, mengorientasikan istinbat hukum dari aspek qaulan (materi hukum) kepada aspek manhajan (kerangka metodologis). Di samping itu, perlu juga memahami pemikiran hukum yang tidak dibatasi sekat-sekat madzhab. Keterbatasan alternatif yang dibingkai dengan sekat madzhab akan menghasilkan produk pemikiran yang rigid (kaku) dan akan mempersulit upaya pembaruan hukum Islam itu sendiri ${ }^{7}$.

Dinamika perubahan sosial dan Islam (hukum Islam) saling memiliki keterkaitan dalam melakukan perubahan. Satu sisi perubahan sosial karena hukum Islam. Di sisi lain, perubahan hukum Islam (mu'amalah) karena perubahan sosial. Keberadaan hukum Islam yang dibawa oleh Rasulullah Saw dengan jelas merubah sosial kultur masyarakat pada waktu itu dari masyarakat jahiliyyah yang berpegang kepada adat kebiasaan mereka menjadi masyarakat Islam yang berpegang kepada hukum Islam. Tetapi hukum Islam juga

${ }^{7}$ Ridwan, Hukum Islam dan Perubahan Sosial. Ibda' Jurnal Studi Islam dan Budaya, Diakses 30 Desember 2017, hlm. 5 melakukan perubahan karena terjadinya perubahan sosial. Sesuai dengan kaidah fikih yang dibuat oleh fuqaha, "berubahnya fatwa dengan sebab berubahnya masa, tempat, keadaan (niat) dan adat kebiasaan". Dengan melakukan perubahan hukum, maka hukum Islam itu dinamis, selalu mampu beradaptasi dengan kondisi kekinian sesuai dengan perkembangan zaman dan perubahan sosial.

\section{Manusia dan Peran Sosialnya}

Terjadinya perubahan sosial tentu ada yang menjadi sebab. Sebab-sebab terjadinya perubahan sosial pada umumnya dapat bersumber pada masyarakat itu sendiri, misalnya antara lain bertambah atau berkurangnya penduduk, pada suatu wilayah tertentu akan merubah sistem pola kehidupan masyarakat. Bertambahnya penduduk suatu wilayah dengan kedatangan transmigrasi tentu akan menjadi penduduk pada wilayah tersebut menjadi heterogen. Penduduk suatu wilayah yang heterogen, yang terdiri dari berbagai latar belakang etnik yang berbeda yang bercampur gaul dengan bebas dan mendisfusikan adat, pengetahuan teknologi dan ideologi, biasanya mengalami kadar perubahan yang pesat akan memudahkan terjadinya perubahan sosial. Begitu pula, timbunan kebudayaan dan penemuan baru, yaitu suatu kebudayaan semakin lama semakin beragam dan bertambah secara akumulatif. Bertimbunnya kebudayaan ini disebabkan adanya penemuan-penemuan baru dari anggota masyarakat. ${ }^{8}$

Perubahan sosial bisa pula terjadi karena faktor eksternal masyarakat tersebut, misalnya yang berasal dari pengaruh kebudayaan masyarakat lain. Adanya perubahan dari masyarakat tradisional ke masyarakat modern karena terpengaruh kebudayaan modern. Masyarakat tradisional adalah masyarakat yang masih kental dengan tradisi setempat

${ }^{8}$ Abdulsyani, Sosiologi Skematika, Teori, dan Terapan, hlm. 164. 
yang dianut oleh mereka secara turun temurun. Masyarakat tradisional diidentikkan dengan masyarakat pedesaan, meskipun tidak semua masyarakat desa bersifat tradisional. Pada masyarakat tradisional seseorang tidak bisa dipisahkan dari lingkungannya. Mereka berhubungan dengan alam secara langsung dan terbuka. Individu dan masyarakat terikat akrab dengan alam semesta. Pada masyarakat tradisional pada umumnya sosial budaya dikuasai oleh tradisi dan kepercayaan, bukan dikuasai oleh hukum dan perundang-undangan. ${ }^{9}$

Manusia tidak dapat hidup terpisah dari manusia lainnya, manusia akan memiliki makna apabila hidup di tengahtengah manusia lainnya. Keharmonisan secara individu akan sangat memudahkan manusia menyesuaikan diri dengan lingkungannya. Manusia secara kodrati juga sebagai makhluk sosial. Sebagai makhluk sosial seseorang individu harus hidup berdampingan dengan orang lain, bahkan makhluk hidup lainnya. Kehidupan sosial, seperti berteman, berkeluarga, bermasyarakat, berbangsa dan bernegara. Kehidupan kelompok dapat mempengaruhi kehidupan individu, demikian juga sebaliknya. Oleh karena itu terjadi kehidupan dalam suatu komunitas, artinya berkelompok bagi yang memiliki kesamaan visi, kepentingan yang sama, kesamaan daerah asal, kesamaan keluarga, bahkan kesamaan darah, dan sebagainya. Terjadilah banyak bentuk komunitas dalam masyarakat. kehidupan pribadi tetap dapat terwujud, namun dalam hal-hal tertentu harus menurunkan atau melakukan penyesuaian dengan komunitasnya. Kalau tidak terjadi toleransi, adaptasi, dan menurunkan tempo individunya, maka tidak akan terjadi kehidupan kelompok tersebut.

Menjaga hubungan baik dengan sesama, maknanya kehidupan seseorang

${ }^{9}$ Pasaribu LL dan B. Simandjuntak, Sosiologi Pembangunan (Bandung: Tarsito, 1986), hlm. 120. individu harus saling membantu, menghargai, menghormati, bersikap toleransi, gotong royong dengan sesama. Manusia dengan kecerdasannya akan mengatur segala bentuk pikirannya. Bukan berarti pikiran yang secara kognitif diakui kecerdasannya akan serta merta berbanding lurus dengan kualitas emosional dan bahkan kepribadian yang mantap. Manusia dalam menjalankan peranan sosial tidak luput dari unsur-unsur agama. Diera modern ini, adanya peningkatan perhatian yang signifikan terhadap agama. Hal ini menurut Dadang Kahmad dalam Naisbitt dan Aburdene, dikarenakan ilmu pengetahuan dan tekhnologi modern tidak memberikan makna tentang kehidupan. ${ }^{10}$

Kegagalan agama-agama di Barat dalam menangani perubahan sosial serta masalah yang ditimbulkannya terlihat dari merajalelanya kultus dan agama yang rendah (sekte-sekte), seperti People's Temple, ${ }^{11}$ Children of God, ${ }^{12}$ dan lainnya.

\footnotetext{
${ }^{10}$ Dadang Kahmad, Sosiologi Agama (Bandung: Remaja Rosdakarya, 2006), hlm. 202203

${ }^{11}$ https://id. wikipedia. org/wiki/Kenisah rakyat . Diakses Tanggal 4 Desember 2017Kenisah Rakyat, yang aslinya dibentuk sebagai Sayap Kebebasan pada 1954, adalah sebuah organisasi keagamaan yang didirikan pada 1955 oleh Pendeta James Warren Jones (Jim Jones). Pada 1960 organisasi ini berafiliasi dengan denominasi Protestan, Murid-murid Kristus. Afiliasi ini merupakan upaya yang berhasil untuk meningkatkan keanggotaan kelompok ini yang makin berkurang dan memulihkan reputasinya. Kenisah Rakyat dikenal karena bunuh diri massal yang terjadi di Jonestown, Guyana, pada 18 November 1978.

${ }^{12} \mathrm{https} / / / \mathrm{id} . \quad$ wikipedia. org/wiki/Children of_God. Diakses Tanggal 4 Desember 2017. Children of God (COG) yang belakangan dikenal sebagai Family of Loves (Keluarga Kasih), Keluarga, dan kini Keluarga Internasional adalah sebuah gerakan agama baru yang dimulai pada 1968 di Huntington Beach, California, Amerika Serikat. Ini adalah bagian dari Jesus Movement (Gerakan Yesus) pada akhir tahun 1960-an. Sebagian besar anggotanya berasal dari gerakan hippie. Gerakan ini adalah salah satu dari banyak
} 
gerakan lainnya yang membangkitkan kontroversi sekte pada tahun 1970-an dan 1980-an di Amerika Serikat dan Eropa dan memicu kelompok anti-sekte terorganisasi pertama (FREECOG).

Sementara gerakan ini bertumbuh dan meluas di seluruh dunia, demikian pula pesannyakeselamatan, Milenarianisme, revolusi rohani melawan dunia luar yang mereka sebut sebagai "Sistem"—dan kontroversi yang muncul sebagai akibatnya. Pada 1974, gerakan ini mulai bereksperimen dengan metode penginjilan yang disebut Menjala dengan Lirikan (Flirty Fishing) dengan menggunakan seks untuk memperlihatkan kasih Allah dan memenangkan anggota baru dan mendapatkan dukungan. Praktik ini dihentikan pada 1987. Pendiri dan pemimpin mereka yang diakui sebagai nabi, David Berg, berkomunikasi dengan para pengikutnya melalui Surat-surat Mo (Mo Letters)-yaitu surat-surat yang berisikan petunjuk dan nasihat tentang berbagai topik rohani dan praktis-hingga ia meninggal dunia pada akhir 1994. Setelah kematiannya, jandanya, Karen Zerby menjadi pemimpin Keluarga.

Kehidupan seksual yang bebas dari kelompok ini, penerbitan dan distribusi tulisantulisan, foto-foto dan video mereka yang menganjurkan dan mendokumentasikan kehidupan seksual antara orang dewasa dan anak-anak, serta seksualisasi anak-anak, menyebabkan munculnya berbagai laporan tentang hubungan seksual antara orang dewasa dan anak-anak. Sejumlah penyidikan hukum dan akademik pada tahun 1990-an menyimpulkan "Keluarga" sebagai sebuah lingkungan yang aman bagi anak-anak, namun penyidikan-penyidikan itupun juga menyoroti masalah-masalah pada masa lampaunya. Pemimpin "Keluarga", yang mengakui bahwa hanya beberapa anak yang mengalami pelecehan sejak 1978 hingga 1985, membuat kebijakan yang melarang hukuman yang berlebihan ataupun kontak seksual apapun antara orang dewasa dan anak-anak kecil. Mereka yang terbukti melecehkan anak-anak setelah Desember 1988 dikucilkan dari keanggotaan "Keluarga". "Keluarga" mewajibkan orang-orang yang memutuskan untuk melaporkan pelecehan anak-anak kepada pihak penegak hukum ataupun melakukan tuntutan hukum terhadap pihak yang dituduh melakukan pelecehan untuk meninggalkan kelompok ini sama sekali. Atau, apabila si tersangka pelaku pelecehan itu telah dikucilkan karena melakukan pelecehan kepada anak-anak, akan diturunkan status keanggotaannya hingga masalahnya diselesaikan. Pada Januari 2005 seorang bekas anggota "Keluarga" dibunuh oleh Ricky Rodriguez, anak angkat pemimpin kelompok ini, yang telah meninggalkan kelompok ini
Semua itiu merupakan konpensasi dari dorongan keagamaan yang tak tersalurkan secara wajar dan refleksi perasaan frustasi masyarakat negara maju. ${ }^{13}$

Manusia dan peran sosialnya dapat diambil contoh seperti kedudukan perempuan dan peran sosialnya di masyarakat. Sejak 14 abad lalu, Islam telah memperhatikan pentingnya kedudukan dan peran perempuan. Menurut padangan Islam, perempuan mampu mengarahkan tanggung jawab atas nasibnya sendiri. Perempuan memiliki posisi penting dalam keluarga dan masyarakat. Oleh karena itu, perempuan memiliki tugas-tugas dan peran tertentu yang dimulai dari institusi keluarga hingga ke berbagai lembaga di masyarakat. Perempuan dapat sebagai pembentuk kepribadian dan karakter individu dan masyarakat.

Dewasa ini, dunia Islam berada dalam kondisi tertentu, di mana peran dan partisipasi konstruktif dari para muslimah sangat diperlukan. Kapasitas dan kemampuan mereka dibutuhkan untuk memperkuat persatuan umat Islam. Oleh karena itu, para muslimah terdorong untuk melaksanakan tanggungjawab mereka dengan baik. Para Muslimah juga tergugah untuk mendirikan sebuah gerakan menyusul adanya upaya musuh-musuh Islam yang tak henti-hentinya berusaha mencoreng citra agama langit ini. Hampir di sepanjang sejarah peradaban manusia, perempuan hanya memainkan peran sosial, ekonomi apalagi politik yang kecil kalau dibandingkan dengan laki-laki. Sebaliknya peran domistik perempuanlah yang lebih menonjol, baik sebagai istri maupun ibu rumah tangga .Asghar Ali Engineer juga mendukung adanya dominasi laki-laki di sepanjang zaman, kecuali dalam masyarakat matriarkhal yang jumlahnya

beberapa tahun sebelumnya. Rodriguez kemudian melakukan bunuh diri. Hal ini mengejutkan anggota-anggota "Keluarga" maupun mereka yang pernah menjadi anggotanya, dan menimbulkan perhatian media yang cukup besar.

${ }^{13}$ Ibid, Dadang Kahmad, hlm. 203 
tidak seberapa, bahkan perempuan dipandang lebih rendah dari laki-laki ${ }^{14}$.

Tradisi yang memandang perempuan sebagai komunitas 'kelas dua' telah mengakar dalam sejarah kebudayaan Arab pra-Islam yang dikenal sebagai zaman Jahilyah. Kedudukan dan status sosial perempuan sangat tidak dihargai. Perempuan secara sosial, ekonomi, dan politik tidaklah bebas, dan tidak dapat memainkan peran yang independen yang dapat menunjukkan harkat dan setatusnya sebagai seorang perempuan. Dalam keluargapun perempuan terlihat lebih termarginalkan, hidup dengan suami yang mempunyai lebih dari dua belas istri. Perempuan dipandang sebagai beban hidup, bahkan di dalam banyak kasus ada usaha-usaha untuk mengubur anak perempuan hidup-hidup sebagaimana yang terekam dalam al-Qur'an: ${ }^{15}$

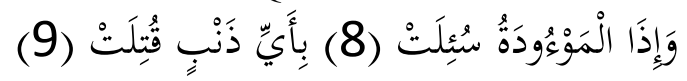

Apabila bayi-bayi perempuan yang dikubur hiduphidup ditanya; karena dosa apakah dia dibunuh" (QS. At-Takwir, 81: 8-9)

Islam meyakini perubahan sebagai suatu realitas yang tidak bisa diingkari. Islam juga memberi posisi yang paling tepat demi memudahkan semua hal untuk berubah secara shahih dan aman. Agama berjalan bersama beriringan dengan lajunya kehidupan. Tugas agama adalah mengawal perubahan secara benar untuk kemaslahatan hidup manusia ${ }^{16}$. Di sinilah sesungguhnya tugas seorang manusia muslim dan peran sosialnya untuk merumuskan pendekatan dan metodologi yang tepat sesuai dengan konteks yang melingkupinya agar agama menjadi fungsional dan bisa membumi. Dalam

\footnotetext{
${ }^{14}$ Ali Engineer, Asghar. Islam dan pembebasan, terj. Hairus Salim dan Imam Baihaqi. (Yogyakarta: LkiS,1993), hlm. 55

${ }^{15}$ Kementrian Agama RI, Al-Quran dan Terjemahannya(Jakarta: Sinergi Pustaka Indonesia, 2012), Juz 81, hlm. 874

${ }^{16}$ Abdul Halim Uways, Figh Statis Dinamis (Bandung: Pustaka Hidayah, 1998), hlm. 221
}

hukum Islam, perubahan sosial budaya dan letak geografis menjadi variabel penting yang ikut mempengaruhi adanya perubahan hukum. Ibnu Qayyim alJauziyah menyatakan bahwa "perubahan fatwa adalah dikarenakan perubahan zaman, tempat, keadaan, dan kebiasaan" Dalam kaidah fiqh lainnya disebutkan "hukum itu berputar bersama illatnya (alasan hukum) dalam mewujudkan dan meniadakan hukum". ${ }^{17}$

\section{Peran Islam Dalam Perubahan Sosial}

Salah satu syarat kehidupan manusia yang teramat penting adalah keyakinan, yang oleh sebagian orang dikatakan sebagai agama. Agama ini bertujuan untuk mencapai kedamaian rohani dan kesejahteraan jasmani. Untuk mencapai kedua ini harus diikuti dengan syarat yaitu percaya dengan adanya Tuhan Yang Maha Esa. Islam memiliki konsep-konsep dasar untuk menggapai keduanya, Islam setiap ajarannya selalu berbicara mengenai kekeluargaan, kemasyarakatan, kenegaraan, perekonomian dan lain-lain. Konsep dasar tersebut memberikan gamabaran tentang ajaran yang berkenaan dengan: hubungan manusia dengan manusia atau disebut pula sebagai ajaran kemasyarakatan. Seluruh konsep kemasyaraktan yang ada bertumpu pada satu nilai, yaitu saling menolong antara sesama manusia. Sebagaimana yang termaktub dalam Surat al-Maidah ayat $2:{ }^{18}$

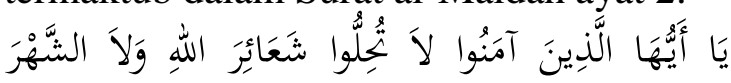

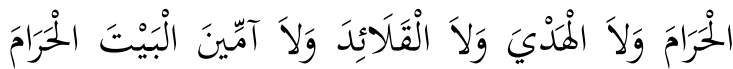

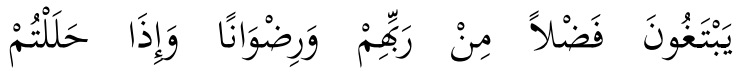

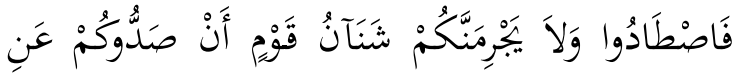

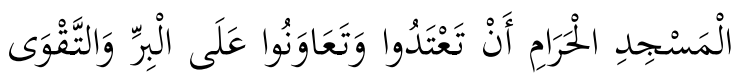

${ }^{17}$ Hasbi ash-Shiddiqie, Falsafah Hukum Islam (Jakarta: Bulan Bintang, 1993), hlm. 444

${ }^{18}$ Kementrian Agama RI, Al-Quran dan Terjemahannya (Jakarta: Sinergi Pustaka Indonesia, 2012), Juz 5, hlm. 141-142 


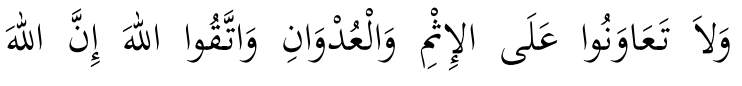
شَدَيْدُ الْعِعَابِ

Hai orang-orang yang beriman, janganlah kamu melanggar syi'ar-syi'ar Allah, dan jangan melanggar kehormatan bulanbulan haram, jangan (mengganggu) binatang-binatang had-ya, dan binatangbinatang qalaa-id, dan jangan (pula) mengganggu orang-orang yang mengunjungi Baitullah sedang mereka mencari kurnia dan keredhaan dari Tuhannyadan apabila kamu telah menyelesaikan ibadah haji, Maka bolehlah berburu. dan janganlah sekali-kali kebencian(mu) kepada sesuatu kaum karena mereka menghalang-halangi kamu dari Masjidilharam, mendorongmu berbuat aniaya (kepada mereka). dan tolong-menolonglah kamu dalam (mengerjakan) kebajikan dan takwa, dan jangan tolong-menolong dalam berbuat dosa dan pelanggaran. dan bertakwalah kamu kepada Allah, Sesungguhnya Allah Amat berat siksa-Nya (Q.S.5:2).

Perubahan sosial yang dikehendaki ajaran Islam adalah perubahan yang memiliki dan mengutamakan nilai-nilai, yaitu perubahan dari suatu yang kurang baik menjadi baik atau yang baik menjadi lebih baik dan segala bentuk perubahan yang terjadi di berbagai bidang harus sesuai dengan norma-norma ajaran Islam. Pada dasarnya perubahan sebagai suatu kemajuan merupakan perubahan yang memberi dan membawa kemajuan pada masyarakat. Hal ini tentu sangat diharapkan karena kemajuan itu bisa memberikan keuntungan dan berbagai kemudahan pada manusia. Perubahan kondisi masyarakat tradisional, dengan kehidupan teknologi yang masih sederhana, menjadi masyarakat maju dengan berbagai kemajuan teknologi yang memberikan berbagai kemudahan merupakan sebuah perkembangan dan pembangunan yang membawa kemajuan. Jadi, pembangunan dalam masyarakat merupakan bentuk perubahan ke arah kemajuan (progress). ${ }^{19}$

Perubahan dalam arti progress misalnya penemuan alat-alat transportasi, dan penemuan alat-alat kedokteran. Adanya kemajuan transportasi memberi kemudahan manusia melakukan segala macam aktivitas, diantaranya aktivitas keagamaan. Penggunaan alat-alat kedokteran yang jauh lebih maju meringankan pekerjaan dan memudahkan manusia memperoleh pelayanan kesehatan yang prima. penemuan alat-alat kedokteran telah memudahkan dan mempercepat manusia dalam proses melaksanakan ibadah Haji contohnya. Salah satu bukti konkret perubahan sosial berpengaruh terhadap hukum Islam adalah munculnya dua pendapat Imam Syafi'i yang dikenal dengan qaul qadim dan qaul jadid. Pendapat lama (qaul qadim) ${ }^{20}$ adalah pendapat hukum Imam Syafi'i ketika beliau berada di Mesir. ${ }^{21}$ Perbedaan

\footnotetext{
${ }^{19}$ Sa'diyah, http://ejournal. stainpamekasan. ac. id/index. php/islamuna/Peran Agama Islam Dalam Perubahan Sosial Masyarakat/Diakses Tanggal 4 Desember 2017

${ }^{20}$ Ibnu Hajar Al Asqolani,TawalliTa'sis Lima'ali Muhammad Bin Idris, (Beirut, Libanon: Darul Kutub Ilmiyah, 1986. ) hal. 147 Qaul qadim adalah pendapat imam Al syafi"i yang pertama kali di fatwakan ketika beliau tinggal di Bagdad Irak $(195 \mathrm{H})$, setelah beliau diberi wewenang untuk berfatwa oleh para ulama/ ahli hadits dan oleh gurunya, yaitu Syeh Muslim bin Kholid (mekah) dan Imam Malik (Madinah). Sebagai tinjauan pendapat Imam abi Hanufah, sebagaimana dikatakan Abdul Ghoni ad Dakir sebagai berikut "Berkata zakaria as saji, telah menghabarkan kepadaku ibrohim bin ziyad, aku mendengar buyuti, telah berkata imam syafi "I: ahli hadits telah bersepakat tentang diriku dan memintaku untuk mengkritik kitab abu hanifah, maka aku katakan: aku tidak tahu bagaimana dia berpendapat hingga aku meninjau kitabnya, maka aku diperintahkan, kemudia aku mendapat tulisan muhamad bin hasan kemudian aku menelaahnya selama satu tahun hingga aku menghafalnya. Baru kemudian aku menulis fatwaku di Baghdad -yakni al hujjah".

${ }^{21}$ M. Atho' Muzdhar, Membaca Gelombang Ijtihad antara Tradisi dan Liberasi (Yogyakarta: Titian Ilahi Press, 1998), hlm. 107
} 
pendapat hukum dalam masalah yang sama dari seorang Mujtahid Imam Syafi'i jelas disebabkan faktor struktur sosial, budaya, letak geografis yang berada antara daerah Iraq (Baghdad) dan Mesir. Ketika Imam Syafi'i berada di Mesir, beliau berusaha meninjau ulang beberapa fatwanya yang diungkpakan di Bagdad.Akibatnya, ada diantara sebagian kitab yang ditetapkan dan ada sebagian kitab yang dikoreksi. Berawal dari kenyataan ini timbullah tema qaul qadim dan qaul jadid, dimana qaul qadim adalah pendapat yang difatwakan di Bagdad dan qaul jadid adalah pendapat yang difatwakan di Mesir. ${ }^{22}$

Menarik untuk di kaji salah satu faktor yang melatar belakangi lahirnya Aqwalu Qodim Wa Aqwalu Jadid adalah faktor sosial. Secara umum, faktor sosial memiliki andil dalam suatu proses perubahan, termasuk dalam fenomena qaul qadim Imam Syafì hingga berubah menjadi qaul jadid. ${ }^{23}$ Di masa kehidupan Syafi i, terutama pada masa awal Dinasti Abbasiyah, kerajaan-kerajaan Islam berada dalam satu payung yang besar, yaitu daulah Islamiyah yang bertujuan untuk terjadi interaksi jasadiyah dan ruhiyah, aqliyah dan fikriyah.di mana saat itu Baghdad menjadi salah satu pusat ilmu pengetahuan dunia. Sebagaimana dikatakan muhamad abu zahroh sebagai beirkut ${ }^{24}$,

"Imam syafi'i lahir pada masa dinasti abasiyah dan hidup pada masa tersebut. Dan hidupnya juga dilikupi social zaman tersebut. Dan (pemikiran) syafi'i juga ditetapkan berdasarkan keadaan zaman dinasti tersebut, dan yang memungkinkan pada pemerintahanya, perkembangan Kehidupan Islam pada masanya. Keistimewaan zaman tersebut

\footnotetext{
${ }^{22}$ Roibin, Sosiologi Hukum Islam: Tela'ah Sosio-Historis Pemikiran Imam Syafi'i, (Malang: UIN Maliki Press, 2008). hlm. 125

${ }^{23} \mathrm{http} / / / \mathrm{id}$. wikipedia. org/wiki/Harun-ArRasyid, Diakses 4 Desember 2017

${ }^{24}$ Muhammad Abu Zahroh, AS Sayafii: Hayatihi Wa 'Asrihi Wa Arouhu Fiqhiyyah, (Damaskus: Darul Fiqr al Arobi, 1987), hal 51
}

mempunyai pengaruh besar dalam duania ilmu pengetahuan, demikian pula pada kebangkitan pemikiran Islam,peninjauan ulama pada filsafat yunani dan peradaban Persia serta keilmuan di india. Dan kami ringkaskan keistimewaan masa tersebut pada perkembangan pemikiran dan keadaan soialnya...".

Untuk menempatkan hukum pada posisi yang betul-betul fungsional dalam menghadapi setiap perubahan sosial, diperlukan terobosan metodologis disertai kemampuan membaca fenomena zaman. Banyak perangkat ilmu yang bisa menopang perumusan hukum menjadi aplikatif, seperti ilmu-ilmu tafsir, tarikh, dan ilmu tata bahasa Arab. Diharapkan melalui pendekatan konvergensi antara ilmu ushul fiqh dan ilmu-ilmu lainnya akan dapat mengurangi formalisme hukum Islam. Dalam konteks ini, pemaknaan hukum Islam tidak harus dilihat dari perspektif nilai saja, tetapi perlu dicari keterkaitan secara organik dan struktural dalam kehidupan sosial. Di sinilah letak pentingnya fenomena transformasi pemikiran hukum Islam, tidak hanya dilihat sebagai fenomena keagamaan saja. Transformasi pemikiran hukum Islam di Indonesia merupakan suatu pergumulan kreatif antara Islam dengan masyarakat, antara nilai-nilai Islam dengan kenyataan struktural masyarakat. Oleh karena itu, maka program pembaruan pemikiran hukum Islam adalah suatu bagian yang tidak terpisahkan dari proses kehidupan masyarakat yang selalu berubah.

\section{E. Misi Islam Dalam Sejarah Perubahan Sosial}

Pada awal kehadiran Islam mengalamai hambatan kultural disebabkan Islam lahir di tengah masyarakat nomaden dan terbelakang (vacuum cultural). Namun dalam perkembangan selanjutnya membuat Dunia terpesona. Dalam jangka waktu yang relative singkat, Islam telah dianut oleh penduduk yang mendiami setengah wilayah dunia. Pada akhir abad ke 20, Agama Islam telah dipeluk oleh lebih dari 
satu milyar penduduk yang tersebar di seluruh dunia, terutama di Asia dan Afrika.

Sebagai sistem ajaran agama yang lengkap, Islam dalam misinya memberi tempat pada dua jenis penghayatan keagamaan. Pertama, eksoterik (zhahiri), yaitu penghayatan keagamaan yang berorientasi pada formalitas fighiyah atau pada norma-norma keagamaan yang ketat. Kedua, esoteric (bathini), yaitu penghayatan keagamaan yang berorientasi dan menitikberatkan pada inti keberagamaan dan tujuan agama. Penghayatan yang berlebihan kepada salah satu dari kedua aspek tersebut kemudian hari memunculkan problematika yang menyalahi prinsip tawazun dalam Islam. Dalam sejarah pemikiran Islam, antara kedua jenis penghayatan keagamaan tersebut sering terjadi problematika, dengan sikap saling menuduh bahwa lawannya telah lari dari konsepsi Islam. Sikap tersebut lebih didasari oleh apriori dan sentiment kelompok yang secara tidak didasari bersikap egosentris. Sehingga kemudian muncullah para tokoh agama untuk mempersatukan kedua jenis penghayatan tersebut, salah satunya seperti yang dilakukan oleh Imam Al-Ghazali dengan karya monumentalnya Ihya Ulum Al-Din memadukan syari'ah (exoterisme) dan sufisme (isoterisme) dalam suatu perpaduan sehingga terjalin hubungan harmonis dan saling menunjang antara keduanya. ${ }^{25}$

Pada masa awal kemunculannya sufisme memposisikan dirinya sebagai gerakan oposisi terhadap dua hal. Pertama, terhadap perumusan Islam yang terlalu menekankan hukum formal (figh). Garapan serius yang menjadi sistem yang terintegrasi dalam Islam adalah bidang hokum. Sedemikian kuatnya segi hukum dari ajaran agama saat itu adalah bentuk kesalahan apapun sering dinyatakan dalam ketaatan pada ketentuan hukum. Kedua, terhadap dekadensi moral akibat kemapaman sosial yang diwarnai dengan kemewahan dan kenikmatan material yang terjadi merata dikalangan masyarakat sebagai akibat dari keberhasilan ekonomi pada masa keemasan di bawah pemerintahan Dinasti Bani Umayyah. Para ulama mengesankan bahwa kehidupan masyarakat pada masa itu kurang religious, sehingga memunculkan kelompok penentang penguasa yang diilhami semangat Hasan Bashri dengan kecendrungan hidup zuhud (asketis). ${ }^{26}$

Pertanyaannya adalah bagaimana misi Islam dalam menerapkan hokum ajaran Islam secara universal dapat diterapkan dalam kesejarahan kemanusiaan yang selalu berubah-ubah. Disinilah harus dipahami benar bahwa perubahan sosial atau praktik dan pemahaman ajaran Islam pada suatu masa tertentu merupakan suatu hasil akumulasi terpadu antara normativitas Islam yang permanen dan sejarah manusia di muka bumi yang selalu berubah. Maka setiap saat setiap zaman selalu terjadi akumulasi dialektik. Dengan demikian akan terjadi reinterpretasi dan reaktualisasi atas ajaran islam yang disesuaikan dengan tingkat pemikiran manusia pada zaman itu.

\section{F. Kesimpulan}

Untuk menempatkan hukum pada posisi yang betul-betul fungsional dalam menghadapi setiap perubahan sosial, diperlukan terobosan metodologis disertai kemampuan membaca fenomena zaman. Banyak perangkat ilmu bantu yang bisa menopang perumusan hukum menjadi aplikatif, seperti ilmu-ilmu tafsir, tarikh, dan ilmu tata bahasa Arab. Diharapkan melalui pendekatan konvergensi antara ilmu ushul fiqh dan ilmu-ilmu lainnya akan dapat mengurangi formalisme hukum Islam.

Dalam konteks ini, pemaknaan hukum Islam tidak harus dilihat dari perspektif nilai saja, tetapi perlu dicari keterkaitan secara organik dan struktural dalam kehidupan sosial. Di sinilah letak

\footnotetext{
${ }^{25}$ Opcid, Dadang Kahmad, hlm. 201
}

${ }^{26}$ Ibid, hlm. 201 
pentingnya fenomena transformasi pemikiran hukum Islam, tidak hanya dilihat sebagai fenomena keagamaan saja. Transformasi pemikiran hukum Islam di Indonesia merupakan suatu pergumulan kreatif antara Islam dengan masyarakat Indonesia, antara nilai-nilai Islam dengan kenyataan struktural masyarakat. Oleh karena itu, maka program pembaruan pemikiran hukum Islam adalah suatu bagian yang tidak terpisahkan dari proses kehidupan masyarakat yang selalu berubah.

\section{DAFTAR PUSTAKA}

Abdul Halim Uways, Fiqh Statis Dinamis (Bandung: Pustaka Hidayah, 1998).

Ali Engineer, Asghar. Islam dan pembebasan, terj. Hairus Salim dan Imam Baihaqi. (Yogyakarta: LkiS,1993).

Dadang Kahmad, Sosiologi Agama (Bandung: Remaja Rosdakarya, 2006).

Hasbi ash-Shiddiqie, Falsafah Hukum Islam (Jakarta: Bulan Bintang, 1993).

Hasanudin. Multi Akad Dalam Transaksi Syariah Kontemporer Pada Lembaga Keuangan Syariah di Indonesia. (Ciputat: UIN Syahid,2009)

H.R. Riyadi Soeprapto, Interaksionisme Simbolik, Perspektif Sosiologi Modern, (Jakarta: PT. Pustaka Pelajar dan Averoes Press Malang, 2001).

Ibnu Hajar Al Asqolani, TawalliTa'sis Lima'ali Muhammad Bin Idris, (Beirut, Libanon: Darul Kutub Ilmiyah, 1986).

Kementrian Agama RI, Al-Quran dan Terjemahannya (Jakarta: Sinergi Pustaka Indonesia, 2012).

M. Atho' Muzdhar, Membaca Gelombang Ijtihad antara Tradisi dan Liberasi
(Yogyakarta: Titian Ilahi Press, 1998).

Musthafa Muhammad az-Zarqa, Hukum Islam dan Perubahan Sosial (Studi Komparatif Delapan Mazhab ) Terj. Ade Dedi Rohayana (Jakarta: Rineka Cipta, 2000).

Muhammad abu zahroh, as sayafii: hayatihi wa 'asrihi wa arouhu fiqhiyyah, (Damaskus: Darul fiqr al arobi, 1987).

Peter Bogason, Public Policy and Local Governance, Institution in Postmodern Society, (Cheltenham, UK: Edward Elgar Publishing Limited, 2001).

Pasaribu LL dan B. Simandjuntak, Sosiologi Pembangunan (Bandung: Tarsito, 1986).

Sanapiah Faisal, Sosiologi Pendidikan, (Surabaya: Usaha Nasional, t.t.).

Soekanto, Soerjono, Sosiologi Suatu Pengantar (Raja Grafindo Persada, Jakarta: 1994).

Sugihen, Bahrein T, Sosiologi Pedesaan (Suatu Pengantar), (Raja Grafindo Persada, Jakarta: 1997)

Soekanto, Soerjono, Pokok-Pokok Sosiologi Hukum, (Raja Grafindo Persada, Jakarta: 2001).

Ridwan, Hukum Islam dan Perubahan Sosial.Ibda' Jurnal Studi Islam dan Budaya, Diakses 30 Desember 2017

Roibin, Sosiologi Hukum Islam: Tela'ah Sosio-Historis Pemikiran Imam Syafi'i, (Malang: UIN Maliki Press, 2008). 
